\title{
Assessing the responsibilities of the United Kingdom and Mauritius towards the Chagossians under international law
}

\author{
Darsheenee Raumnauth (1), Roopanand Mahadew(2)' \\ (I) African Union Commission, Ethiopia \\ (2) Department of Law, University of Mauritius, Mauritius
}

\begin{abstract}
This article reviews the obligations under international law of the United Kingdom and Mauritius towards the Chagossians. With the detachment of Chagos from Mauritius as an essential condition for the independence of Mauritius from the British colonial master, the Chagossians have, over the past four decades, endured enormous human rights violations. This article assesses the responsibility of the two states vis-à-vis the Chagossians. A comprehensive factual account is first presented to clarify understanding of the history of Chagos. The legal framework is then analysed to assess the responsibility of each state, before a number of recommendations are made.
\end{abstract}

Key words: Chagos, Mauritius, United Kingdom, British Indian Ocean territories

\section{Introduction}

A Factual account

Known as the largest and only inhabited coral island of the Chagos Archipelago (Gifford, 2004: 2), Diego Garcia, the horseshoe-shaped atoll is equally renowned as a site for one of a number of secretive U.S military bases in the Indian Ocean. However, while this latter aspect is frequently prominent, it is typically overlooked in mainstream discussions in relation to militarisation, world peace and security (Boolell, 2010: 29). For example, this issue seems to have been almost wholly ignored during consultations on nuclear disarmament in Africa (Pelindaba Treaty, Ig66) even though Mauritius and Diego Garcia irrefutably form an integral part of the African Continent (Collen, 2009).

Getting to the roots of the story behind the tiny atoll, it has been claimed that Mauritius sold this particular island to the United Kingdom at the time of its negotiations pertaining to its independence in 1965 (Boolell, 2010). Nevertheless, against such a claim, the idea that there was consent among the Mauritian delegation on the issue of selling Diego Garcia remains dubious, as the latter still holds conflicting views pertaining to

Constitutionalism and Rule of Law Analyst (African Union Commission) Human Rights and International Law Lecturer University of Mauritius) and doctoral candidate at the University of the Western Cape South Africa. 
their consent (Sookhoo, Le Mauricien: 2013). Together with this concern, it is also important to note that despite presently being a British Indian Ocean Territory (BIOT), the island is a United States (US) military base (Snoxell, 2009: I30). More precisely, despite the fact that the UK holds legal ownership of Diego Garcia, the atoll is in fact used as a military base by the US with some 5000 US soldiers, and a mere handful of British citizens who have the charge of handling administrative issues. To further muddy the waters, the US has even been claimed to be the decision maker in relation to the BIOT.

There is, in fact, an awkward and fragile rapport between the US and UK that can be seen whenever the issue of Diego Garcia is raised. In particular, whenever the issues of accountability and responsibility pertaining to the human rights violations inflicted on the Chagossians emerge, both the US and the UK engage in a kind of tennis in which responsibility is hit into each other's court as a form of evasion. Consequently, uncomfortable questions with regard to Diego Garcia are cautiously and tactically circumvented. However, ultimately, it is the unfortunate and helpless Diego Garcia Islanders who, for the past 40 years have been left stranded in awfully dreadful conditions in Mauritius, who suffer from such tactical games. The islanders have to live with the bitter reality of having been deprived of their birth right, their right to their homeland (Vine, 2005: 5) and are still forbidden from having access to their very own island. Taking into consideration that this subject has an imperative historical, legal and political framework linked to the human rights violations perpetrated on the Chagossians, the aim behind this article is to closely scrutinize the responsibilities of the UK and Mauritius towards the Chagossians under international human rights law, and the extent to which those responsibilities have been met, given that having been forcefully evicted from their homeland they are reside in these two countries. Particular focus is laid on the State of Mauritius which arguably may be avoiding its obligations towards the Chagossians by taking advantage of the fact that from a political perspective the international focus on the issue is on the UK. Further, this article demonstrates how both countries must share the responsibility remedying the grave and ongoing injustice against the Chagossians.

\section{The responsibilities of UK towards the Chagossians under international law}

Whenever individuals are deracinated from their roots, their motherland, no level of compensation can make up for the physiological ordeal and the loss they have to endure (Vine, 2006: 2I). As a matter of fact, the eviction of the Chagossians from their very own country was not only an matter of material cost or a breach of right to property as provided for under article 17 of the Universal Declaration of Human Rights (UDHR, art I7), but also encompassed the infringements of articles 2 (Prohibition of discrimination), I 3 (Freedom of movement, entry and exit), I4 Right to asylum), I5 (Right to nationality), 23 (Right to work) and 25 (Right to adequate standard of living and health) of the Universal Declaration. Moreover, in the case of the unfortunate Chagossians, the fear of persecution, threat and coercion as brought up by article I of the International Convention on Torture (CAT, art I) also became a situation of permanent exile hence equally violating article 9 of the Universal Declaration. It is to be underlined that a comprehensive analy- 
sis of the International Covenants illustrates that both of them condemn the deliberate permanent displacement of individuals from their territory under articles I of the ICCPR and the ICESCR on self-determination. As a matter of fact, it can be clearly seen that the violations of human rights faced by the Chagossians cut across across a broad spectrum of the Conventions.

The UK's role in the displacement of the Chagossians, can irrefutably be termed as a breach of international law (Pilger website, 2015) 'sweeping and sanitizing the island of its population' is a breach of international law (Pilger, 2015). It should be stressed that this fact is no longer an ambiguous point in the international community and on the judicial front; and therefore the UK is clearly liable for the harm it has caused to the Chagossians and should therefore provide them with effective compensation. Moreover, the UK is not only bound under its own national legislation and customary international law, but it also owes a moral and ethical responsibility towards the Chagossians for the inhuman treatment inflicted on them.

As per schedule 3 of the British Nationality Act I98I, the BIOT is considered as a British dependent territory. Subsequently, such a classification emphasises the UK's obligationto meet its responsibilities towards all those Chagossians who are British citizens. In addition, there is no declaration or reservation made by the UK with the effect that the human rights treaties it has ratified by the latter is not applicable to the BIOT.

\section{Why does the UK have a responsibility towards Chagossians?}

Whenever any state ratifies international human rights treaties, it embarks on the implementation on domestic measures and legislations which are in conformity with obligations and duties applicable to them on being party to the treaty. Hence, having ratified the ICCPR and the ICESCR, the UK has bound itself to provide for the Chagossians who qualify as British citizens. It is significant to highlight here that together with the treaties it has ratified, the UK is also bound by the obligation under the Universal Declaration to sustain fundamental human rights. Also, in this respect, even if declarations are normally non-binding, the Universal Declaration has achieved the status of customary international law and thus all states are bound by the obligation to respect, promote and fulfil the rights stipulated in it. In this light, Hannum aptly says that the Universal Declaration has an incontrovertible 'political standing and symbolic importance' and it remains an authoritative enumeration of universally recognised human rights which constitutes an obligation for state parties to adhere to their duties towards all members of the human family (Hannum, I995: 287). In contrast, General Comments continue to be authoritative interpretations of the provisions in the Universal Declaration and ICESCR respectively (Max Planck website, 2014) whereby Langord explains that they have a significant role to play in 'progressive norm creation' (Langford, 2012, 33) but they are mainly of high moral and political persuasive value to countries instead of having a legally binding status.

It is again important to note that Article I4(2) of the Articles on State Responsibility for Internationally Wrongful Acts drafted by the International Law Commission (ILC) in 
200I makes clear that legislative measures infringing the Covenant would draw responsibility. In this respect, James Crawford maintains that the rationale is that legislative measures substantiate the ongoing violation of an international obligation (Crawford, I999: 372). In the same way, the legislative denial of the right of abode of the Chagossians in section 4 of the BIOT Immigration Ordinance (I97I) and the 2004 Orders in Council delivers supplementary evidence of an act that violated the Covenant rights of the Chagossians for which the UK should bear responsibility.

At the same time, the United Nations Basic Principles and Guidelines on the Right to a Remedy and Reparation for Victims of Gross Violations of International Human Rights Law and Serious Violations of International Humanitarian law (2005) brings forward the argument that the pecuniary value of the detriment that people evicted from their homeland suffer should be gauged so that sufficient compensation may be provided. Nevertheless, it is significant to note at this stage that the adequacy of the compensation given by the UK to the Chagossians, the sufficiency is very much disputed.

Again, the UN Declaration of Basic Principles of Justice for Victims of Crime and Abuse of Power provides that victims should have access to ample and effective remedies whereby Article 4 in particular elaborates on the access to justice of victims while Article 5 deliberates their fair treatment. Hence if the concept of victims is applied to all those Chagossians who have had to endure the terrible ordeals of psychological trauma, deprivation and exclusion, and the offender in these terms is the UK, such a declaration depicts a convincing argument as to what the UK's obligations towards them are. Actually, the range of legislations underlines that from the moment of their displacement the right to return to their own country had been denied to the Chagossians. Subsequently, such a deprivation has had a large negative effect on several of their other rights in the civil, political and social and economic fields.

It is interesting to mention here that Vine et al. contend that the compensation provisions made for the Chagossians by the UK in the I970s and early I980s were far from adequate (Vine, 2006:2I). in the Specifically, early I970s the UK granted Mauritius the amount of $£ 650,000$ in order to assist the Chagossians' resettlement in the country (De L'Estrac, 20II, 35). Moreover, in I982, the Chagossian leaders were for the first time given the chance to voicetheir protests. As a matter of fact, the UK Government, the Mauritian Government and the Chagossian representatives stepped forward to make an agreement under which an additional $£_{4}$ million was paid by the UK Government into a trust fund for the welfare of the registered Chagossians. Nevertheless, not all of the Chagossians benefited from this compensation as unfortunately not all of them were registered. To make matters worse the UK government saw this compensation as the complete settlement of all claims that the Chagos Islanders might have had (Chagos Islander v UK, 2012). Nonetheless, many of them claimed to have received too little compensation (Jeffrey, 2006: 29). It is also disappointing to note that even if their right to return as provided for by articles 9 and ${ }_{3} 3$ of the Universal Declaration was repeatedly repudiated, there was no attempt made by the UK government to ensure that their resettlement was done in accordance with the UN guiding principles on resettlement. 


\section{Assessing the responsibilities of UK under the ICCPR}

Pertaining to the responsibilities of the UK, the UN Human Rights Committee (UNHRC), with reference to General Comments I5 and 3I on Article 2 of the ICCPR has elucidated that the Covenant is applicable to 'all individuals regardless of nationality and statelessness'. Such was accentuated on during the discussion of the extraterritorial scope and meaning of 'jurisdiction' under the jurisdictional test under article 2(I) of the Covenant. States in fact have an obligation towards all irrespective of who or where the individuals are. Hence, under Article 2 of the ICCPR, the UK has an obligation towards the Chagossians irrespective of whether or not they are entitled the British Citizenship.

It is also significant that in terms of the application of international human rights law principles and obligations to extra territorial action, General Comments ${ }_{5}$ and $3 \mathrm{I}$ retain anexplicit position. They maintain that rules regarding the basic rights of humans are erga omnes obligations. Actually, many states also raise the non-nationality element when deciding on whether they should extend human rights protection extra territorially. Nevertheless, in the case concerned, the target group in question are British citizens and are therefore directly linked to the UK. In addition, the jurisdiction here is in fact a BIOT which is a British Dependent territory and hence the island is more of an 'extended' territory of the UK rather than 'extra- territorial'.

Taking into consideration that the Chagossians fell victim to forced exile without their permission the HRC has explicitly put forward that state acts effected outside of the territory of a state party to the ICCPR against someone within the jurisdiction of that state are subject to examination under the ICCPR (General Comment NoI5, 3). Subsequently, as citizens of the UK, Chagossians are irrefutably within that nation's jurisdiction, irrespective of where they live and regardless of whether the ICCPR applies to the BIOT itself. It should also be considered that the ICCPR cannot be deemed invalid in this situation as the majority of the group reside outside British territory. Finally, having already established the jurisdiction of the applicability of the ICCPR to the BIOT, the responsibilities of UK can be determined. Hence, the UK has an obligation to make provisions for the civil and political rights of its citizens under the ICCPR, more precisely under article I of the covenant by respecting the right to self-determination of the Chagossians.

As per Article I of the ICCPR, all peoples have the right of self-determination. By virtue of that right they freely determine their political status and freely pursue their economic, social and cultural development. Maureen Tong contends that that Chagossians have the right to return and the right to self-determination for the simple reason that they have been present on the land for many generations (Tong, 2009: I0).

At the same time, it should also be considered that when the decision to forcefully exile the group was taken, none of them were shown due respect thus constituting a breach of article I of the ICCPR. Consequently, article I(2) poses an obligation on the UK to make provisions for the Chagossians as the latter was dispossessed of his own means of survival. Also, Article I(3) of the ICCPR binds the UK to adhere by the provisions of the United Nations Charter in the promotion of the realisation of the right of self-determination since it is responsible for the administration of the territory. Finally, the UK 
also has an obligation under article I2(4) of the ICCPR which states that 'No one shall be arbitrarily deprived of the right to enter his own country' and to allow the Chagossians the right to return.

\section{Assessing the responsibilities of the UK under the ICESCR}

Before putting forward the responsibilities of the UK under the ICESCR, it is important to underline that the ICCPR and the ICESCR are in parallel to each other. Hence, as the UNHRC has brought forward the application of the ICCPR to the BIOT this can also be used to evaluate UK's obligation to apply the provisions of the ICESCR in the territory since the rights are indivisible, interdependent and interrelated. As a matter of fact, the rights provided for by the ICESCR are particularly relevant and significant to the resettlement of the Chagossians.

Article I of the ICESCR also provides for the right to self-determination. Considering that this article has been breached by the UK by depriving the Chagossians of their right to have access to the island, the offender country is bound by the obligation of not obstructing the enjoyment of the other rights of the Chagos Islanders. At this stage, reference can also be made to Article II of the ICESCR which provides that a state has a legal commitment to provide for its citizens to secure an adequate and developing standard of living, especially in the domains of employment, welfare provision, housing, healthcare, education and cultural expression. Nevertheless, there has allegedly been a number of cases in which newly arrived British Chagossians have been made to wait for 3 months by the UK immigration department before being provided with allowances. The upshot of such action is that they had to face considerable impediments during their stay in the UK.

Moreover, General Comment 3 of the Economic, Social and Cultural Rights (ESCR) Committee states that 'a State party would be failing to discharge its minimum obligations under the Covenant if a significant number of individuals were deprived of essential primary healthcare, basic housing and education.'

However it is imperative to be clear on the fact that even if one of the basic premises of the ICESCR is progressive realisation subject to adequate resources, the UK remains one of the biggest economies of Europe which does not at all make it valid for the latter to put forward the excuse of insufficient funds for the Chagossians' cause. Hence, the conscious exclusion of an ample well planned funding programme of the resettlement of the Chagossians irrespective of their location is a prima facie breach of the Covenant.

As per Article 2(I) of the ICESCR: States have the obligation to implement the necessary mechanisms and institutions for the realisation of the rights enshrined in the Convention. At the same time, in General Comment 3, the Committee elucidates that State parties must ensure that Covenant rights are realised 'by all appropriate means'. This embraces allowing 'for a broad range of measures that extend beyond the enactment of legislation and judicial remedies to include administrative, financial, educational and social measures.'

As a matter of fact, the right to a judicial remedy strengthens the realisation of the right in many cases. Nevertheless in contrast with the ICCPR, the ICESCR does not com- 
prehend the right to a judicial remedy. Hence in order to fill this gap, the Committee in General Comment 9 indicated that: Covenant norms must be recognised in appropriate ways within the domestic legal order, appropriate means of redress, or remedies, must be available to aggrieved individuals or groups, and appropriate means for ensuring government accountability must be put in place (para 3 ).

Consequently, the Chagossians may have access to judicial remedy in cases of nonfulfilment of rights. It should be noted that despite following a dualist approach the UK has not yet incorporated the ICESCR in its domestic laws. Nevertheless, General Comment 9 places an obligation on State parties to provide appropriate remedies for human rights violations under the Covenant obligations irrespective of whether or not such obligations have been incorporated into domestic law. Hence, considering this aspect, the government of UK has certain obligations towards the Chagossians.

\section{Responsibilities under the International Convention on Elimination of \\ Racial Discrimination (ICERD)}

Racial discrimination is one of the various predicaments faced by the Chagos Islanders. It has been aptly put by Vine that the element of race contributed to a large extent in the eviction of the miserable Chagossians (Vine, 2006: 2I). This can be evidenced by the mere fact that even though they had always inhabited the land, certainly well before the arrival of the British, they were erroneously described as temporary contract workers by the UK (Jeffrey, 2006: 29). Furthermore, despite the fact that many Chagossians qualified for British citizenship, they are still deprived of monetary assistance to obtain a British passport demonstrating the unwillingness on the part of the UK government to integrate the Chagossians.

Article 6 of the ICERD obliges State parties to guarantee that 'everyone within their jurisdiction has access to effective protection and remedies, through the competent national tribunals and other State institutions, against any acts of racial discrimination'. Hence, even if the UK government has constantly asserted that the ICCPR and the ICESCR are not applicable to the BIOT, no territorial declaration with regard to the non- territorial or extra territorial application of this convention to the BIOT had been made. Likewise, there is no such evidence of any attempt by the UK government to exclude the application of ICERD in the BIOT.

Article I(I) of ICERD defines the term 'racial discrimination' as referring to any distinction, exclusion, restriction or preference based on race, colour, descent, or national or ethnic origin which has the purpose or effect of nullifying or impairing the recognition, enjoyment or exercise, on an equal footing, of human rights and fundamental freedoms in the political, economic, social, cultural or any other field of public life. Under this article, the rights of the Chagossians to participate in political, economic, social and cultural public life have been impaired.

Comparing the cases of several islands which are entitled as British Dependent Territories, the case of Chagos can be termed as being a unique one for it is the first island whereby islanders have been evicted from their ancestral homelands. Hence, in order 
to scrutinise whether UK is accomplishing its obligation under the Convention towards Chagossians, it would be valid to compare the other ethnic groups who are currently living in the UK. Therefore, on making an analysis of the approach and assistance of the UK towards inhabitants of the Falklands islands who are of Caucasian origin, it can be thoroughly observed that the UK has demonstrated unflinching support towards respecting their rights to self-determination and the right to stay on their homeland. Subsequently, the contrast in the approach of the UK towards both islands indubitably reflects the blemish of racism directed towards the Chagossians.

Furthermore, Chagossians are entitled to be protected against discrimination through the recognition and provision of a wide range of rights encompassing the right to 'freedom of movement and residence within the border of the State and to return to one's country' under article 5 of the ICERD. Nevertheless, concluding observations from several committees show that UK has intentionally omitted the information on BIOT as applicable under the different covenants. In 2003, after the UK presented its I6th and the I7th report to the Committee, the latter requested the UK in the concluding observations to arrange for information on the implementation of the ICERD in the BIOT in its next report and also to intensify on the measures taken to guarantee the sufficient development and protection of the Chagossian people's rights under the Convention. Also, CERD's specific reference to Article 2(2) in this context designates that it considers that 'special measures' would be necessary in order to avoid a situation of discrimination. In the BIOT context, special measures might focus on the protection and promotion of the Chagossian people's right to return to their homeland.

\section{Responsibilities of the UK under the Magna Carta}

As a matter of fact, the different principles of equality, non-discrimination and respect for human dignity form an integral part of the Magna Carta. Most importantly, even if the UK may assert the non-applicability of the international conventions to the BIOT, the principles of the Magna Carta irrefutably extends application to the British Dependent territory as the latter is part and parcel of British governance and management. Subsequently, whether or not the UK agrees, it cannot be overlooked that the latter has an obligation under article 52 of the Magna Carta to guarantee that Chagossians are not discriminated against and to ensure the restitution of those who have been evicted.

\section{How far have they abided by their responsibilities?}

The latest development in the legal frameworkis the development of a Marine Protected Area (MPA) around the Chagos Islands, strong indication of the UK's loyalty to the US. It remains a harsh reality that the vulnerable Chagossians are not only being banned from exercising their right to return and their right to self-determination on Diego Garcia, but they are also excluded from all the other islands in the archipelago. Besides, there can be no better proof than the non-inclusion of the obligations in the country reports submitted by the UK to the HRC and the denial of the applicability of the different Conventions that would underline how they have been shirking their responsibilities. Fur- 
thermore their claim in the ECtHR that the compensation was ample and that no more can be given shows how the political establishment has reneged on its responsibilities.

Taking into consideration the actions adopted by the UK starting through the Royal Prerogative to refuting the courts' decision by enacting other laws such as the BIOT (Constitution) Act and the BIOT (Immigration) Order 2004, it can be concluded that their responsibilities and obligations towards the Chagossians are not being given the required attention. It cannot be disregarded that the repudiation of their right to return has manifold effects on the non-enjoyment of other human rights. Their decision, as is appositely designated by John Stubb, 'is peppered with statements regarding the judicial/political mire of balancing human rights issues with national security and defence considerations and sympathetic statements regarding the plight of the Chagossians.'

\section{Responsibilities of Mauritius towards Mauritian Chagossians}

As stated above, the decision that was taken by the Mauritian Delegation during the independence negotiations on the 8th of November 1965 was pivotal for the fate of many Chagossians who are still living in dreadful conditions in Mauritius (Geoffrey, 2012: 12). Mauritius perceives this dispute as centring on the sovereignty over the Chagos Islands as an issue of ongoing decolonisation. It might be of interest to note at this stage that during earlier times, successive Mauritian governments were also hostile to the Chagossians whenever they called for their right to return. Conversely, in later years, Mauritius has demonstrated a firmly supportiveattitude towards the Chagossians and entirely supported them in their fight to returnto their homeland. More importantly, in the year 2007 , the former president of the country, Sir Aneerood Jugnauth threatened to leave the Commonwealth and drag the UK to the International Court of Justice (ICJ) if the Chagossians' issue was not resolved speedily (Ilois trust website, 20I4).

The foremost segment of the Chagossians who were cast out of their homeland from the island now reside in Mauritius where they are living in the regions of Cassis and Roche-Bois, which are in the suburban region of the national capital, Port Louis. It might be of interest to mention here that these regions have been categorized as being the most poverty stricken areas of the island. Moreover, even if Mauritius asserts that no segment of its population lives on less than \$I per day in the national report submitted to the Universal Periodic Review (UPR, 2013), this is not at all the case for the Chagossians. The harsh reality is that they live in miserable conditions with dilapidated iron roof houses and work as unskilled labourers (TRC Report, 20II). Another issue that arises from their plight isthat their socio- economic rights are not being fulfilled.

\section{Analysis of the responsibilities of Mauritius under its Constitution}

Taking into consideration that Mauritius claims to hold sovereignty over Diego Garcia, the issue of the Chagos Islanders can be gauged from a constitutional rights point of view (Abraham, 20II: I28). At this stage, it becomes imperative to highlight the fact that as per section III(I) of the Mauritian Constitution, 'the island of Mauritius includes the small islands which are adjacent to the island of Mauritius and as per section III(I) (a) 
of the Mauritian Constitution, Mauritius' includes the Islands of Mauritius, Rodrigues, Agalega, Tromelin, Cargados Carajos and the Chagos Archipelago, including Diego Garcia and any other island comprised in the State of Mauritius.

Moreover, if an analysis of the section III(I) (a) is made, it can be observed that even if Mauritius had received $£_{3}$ million for the excision of the Chagos Archipelago in I965, it still included the ownership of the island when the Constitution was drafted in I968. Nevertheless, whether this involved a legal or political issue is still a matter of great debate.

Also, as the Constitution of Mauritius is the supreme law of the island and with Diego Garcia being mentioned in it, it can be undoubtedly understood that Mauritius took complete charge of what happens on its territory. It is also to be noted that as per section 3 of the Mauritian constitution, it has been provided that in Mauritius there have existed and shall continue to exist without discrimination by reason of race, place of origin, political opinions, colour, creed or sex, but subject to respect for the rights and freedoms of others and for the public interest, each and all of the following human rights and fundamental freedoms. Subsequently, it becomes obvious by adherence to this section of the Constitution, Mauritius is bound by the obligation of not discriminating against the vulnerable Chagossians, but unfortunately this is not what happens in reality.

De L'Estrac rightly states that the conceited role that Mauritius actually plays as a victim of UK's realpolitik and manipulation remains one of the major problems affecting the Chagos Islanders. It was valid to have certain expectations of the Mauritian Authorities concerning the ample provisions of housing, jobs and schools to the chagossians but unbelievably, the Chagossians were dumped on the docks of the capital like cattle and left to fend for themselves. Moreover, considering section 8 of the Mauritian Constitution pertaining to the unlawful deprivation of property, the eviction of the Chagossians from their island was an unlawful deprivation of property under section 8 (b) of the Constitution which states that there should be a 'reasonable justification for the causing of any hardship that may result to any person having an interest or right over the property'. It should be stressed here that the forced removal of the Chagossians from their own land in such a treacherous way can in no way be considered a valid excuse. At the same time, section 8(c) of the Constitution places an obligation on the state to implement a law which is applicable to acquisition of property for the payment of sufficient compensation. Hence, indubitably, Mauritius is liable to the Chagossians with regard to the compensation to which they have all the rights. Coming up to section 26 of the Mauritian Constitution, the powers of the parliament has been provided for whereby if this is applied to the case of the Chagos Islanders, sections 26(I) (a) and 26(I)(d) are of precise relevance which provides that: Parliament may make provision.

(a) For the acquisition of citizenship of Mauritius by persons who are not eligible or who are no longer eligible to become citizens of Mauritius by virtue of this Chapter.

(d) For the maintenance of a register of citizens of Mauritius who are also citizens of other countries. 
Finally, it is also significant to mention here that Robin Mardemootoo, the lawyer representing the Chagossians cause in Mauritiusexplicitly highlighted that since the issue of the Chagossians is a highly political one, the Parliament can definitely make amends for the wrongs inflicted on the Chagossians. Consequently, under article 26(b) of the Constitution, Mauritius does not need to wait for UK to take action for the Chagossians especially as it considers that it has sovereignty over the land. Hence, it can address the issue of non-registered Chagossians so that the issue of compensation may be carried out aptly as well.

\section{Responsibilities under the Universal Declaration of Human Rights}

Mauritius is bound by customary international law to shield the Chagossians by articles 2 and 9 of the Universal Declaration. Together with this, it also has to assume responsibility towards them under article I2(I) and I2(4) of the ICCPR which states that: I. Everyone lawfully within the territory of a State shall, within that territory, have the right to liberty of movement and freedom to choose his residence.

4. No one shall be arbitrarily deprived of the right to enter his own country.

Nevertheless, Mauritius has infringed the right to liberty of the latter, most particularly by taking away from the Chagossians the right to choose their residence. At this stage, it is important to be clear that Mauritius was never their residence, but even then they were compelled to stay there for the simple reason that they had been subject to exile. Also, even in Mauritius, they were not allowed the freedom to choose their residence and were put in slum areas of the island. There is no doubt that this constitutes a violation of article I2(I) by the state. At the same time, as per Article 27 of the ICCPR, Mauritius also has the obligation to protect minorities. Hence, bearing in mind that Chagossians have a distinct cultural identity and speak Chagossian creole (which is different from the Mauritian creole spoken in the country), Mauritius has an obligation to make provision for the full enjoyment of the Chagossians' right under article 27 of the ICCPR. As a matter of fact, more than an attitude of tolerance towards Chagossians, Mauritius needs to demonstrate an attitude of integration. The UN Special Rapporteur of the United Nations Sub-Commission on Prevention of Discrimination and Protection of Minorities, Francesco Capotorti, explicitly asserted that special attention must to be paid to issues such as efforts to 'guarantee their rights to non-discrimination and equality; the inclusion of their concerns in development and poverty-reduction processes and disparities in social indicators such as employment, health and housing' while addressing the protection of minorities' human rights. Nevertheless, Mauritius has infringed the right to liberty of the latter, most particularly by taking away from the Chagossians the right to choose their residence. At this stage, it is important to be clear that Mauritius was never their residence, but even then they were compelled to stay there for the simple reason that they had been subject to exile. Also, even in Mauritius, they were not allowed the freedom to choose their residence and were put in slum areas of the island. There is no doubt that this constitutes a violation of article I2(I) by the state. At the same time, as per 
Article 27 of the ICCPR, Mauritius also has the obligation to protect minorities. Hence, bearing in mind that Chagossians have a distinct cultural identity and speak Chagossian creole (which is different from the Mauritian creole spoken in the country), Mauritius has an obligation to make provision for the full enjoyment of the Chagossians' right under article 27 of the ICCPR. As a matter of fact, more than an attitude of tolerance towards Chagossians, Mauritius needs to demonstrate an attitude of integration. The UN Special Rapporteur of the United Nations Sub-Commission on Prevention of Discrimination and Protection of Minorities, Francesco Capotorti, explicitly asserted that special attention must to be paid to issues such as efforts to 'guarantee their rights to non-discrimination and equality; the inclusion of their concerns in development and poverty-reduction processes and disparities in social indicators such as employment, health and housing' while addressing the protection of minorities' human rights.

\section{Responsibilities under ICESCR}

Shedding light on the fact that the Chagossians were left to fend for themselves in the new territory and so have been denied a satisfactory resettlement program, Mauritius had the ultimate responsibility to guarantee that the resettlement program was carried out in conformity with the rule of law. As per Article 6 of the ICESCR, state parties have the obligation to recognise the right to work 'which includes the right of everyone to the opportunity to gain his living by work which he freely chooses or accepts'. Similarly, Article 6(2) of the ICESCR places an obligation on states to take tangible steps to accomplish the right to work which includes providing technical and vocational guidance and training programmes, policies and techniques to attain firm economic, social and cultural development and full and productive employment under conditions preserving fundamental political and economic freedom to the individual. In addition, it has been provided by Article 7 of the ICESCR that

The States Parties to the present Covenant recognize the right of everyone to the enjoyment of just and favourable conditions of work which ensure, in particular:

(a) Remuneration which provides all workers, as a minimum, with:

(i) Fair wages and equal remuneration for work of equal value without distinction of any kind, in particular women being guaranteed conditions of work not inferior to those enjoyed by men, with equal pay for equal work;

(ii) A decent living for themselves and their families in accordance with the provisions of the present Covenant;

(b) Safe and healthy working conditions;

(c) Equal opportunity for everyone to be promoted in his employment to an appropriate higher level, subject to no considerations other than those of seniority and competence.

Nevertheless as mentioned above, most male Chagossians work in the unskilled labour field as labourers hence demonstrating a non-obligation by the state under articles 6 and 7 of the ICCPR. It has been very well contended by Bunwaree that there is an unparadisical side to the paradise image that Mauritius retains on the international fora 
(Bunwaree \& Kasenally, 2007). The malaise creole, which is not adequately discussed, affects the Chagossians directly.

Responsibilities of Mauritius under the African Charter on human and peoples' rights

Mauritius is also bound to the African Charter by virtue of being a State party whereby Articles 2, I2 and 20 of the African Charter are of utmost relevance to the case of the Chagossians. In this respect, Mauritius has an obligation towards the Chagossians to realise their right to self-determination, recognise that they have a right to freedom of movement and should not be arbitrarily deprived of entering their own country (Evers, 20II). Further, Mauritius can specifically hunt for support from the African community to rally to the cause of the Chagossians.

How far has Mauritius abided by its responsibilities?

Kisto has revealed that the step of making housing provisions for the Chagossians is not at all adequate to accomplish all their socio economic rights. More precisely, such a step is not complete without providing job opportunities, the only way to enable them to enhance their living standards and meet the needs of their families. At the same time, as explained above, the self-reliance and the local integration policies as established by the UN guidelines on resettlement have not been adhered to by the Mauritian government and it has not included reports about the Chagossians to the UPR mechanisms or the other UN committees to avoid the issue of accountability.

\section{Extra obligations on Mauritius towards the Chagossians}

Together with the responsibilities that Mauritius has towards the Chagossians Mauritian citizens, it is imperative to observe that such responsibilities even extend to the non-nationals of Britain and Mauritius. International human rights law places an obligation on states to cater for the rights of nationals and non- nationals similarly, regardless of their legal status. Hence, Mauritius also has the territorial responsibility under international human rights law to cater for this third group of Chagossians who are those who are neither British nor Mauritians residing in the Mauritian territory.

\section{Analysis of the law and normative framework}

The UN Declaration on the Principles of International Law concerning Friendly Relations and Co-operation among States maintains that a 'people' of a non-self-governing territory preserve a separate and distinct legal status from its administering State and this status remains until the people have exercised their right of self-determination. As a matter of fact, both Mauritius and UK have disputed the other's claim to sovereignty over the island of Diego Garcia, but when it comes to taking responsibility for the resettlement and compensation of the Chagossians neither party will accept accountability. Hence, for the benefit of the Chagossians, a middle ground can be reached so that their plight can be addressed, with special focus on the stateless Chagossians who cannot benefit from either side. 


\section{International Conventions}

The UN Conventions related to the status of refugees and stateless persons are the International Convention on the Status of Refugees, International Convention on the Status of Stateless Persons and International Convention on the Reduction of Stateless. Nevertheless, taking into consideration that Mauritius has not ratified any of these Conventions, it becomes difficult to scrutinize its responsibilities under this umbrella as it is not legally binding on Mauritius.

Within the African human rights system, the conventions are the OAU Convention Governing the Specific Aspects of Refugee Problems in Africa and the International Convention on the Internally Displaced Individuals. Again none of these conventions have been ratified by Mauritius. Nevertheless, despite not being able to hold the country accountable under both the UN and the AU mechanism of human rights protection, it remains bound under customary international law through the Universal Declaration.

Non-ratification by Mauritius of conventions related to refugees and internally displaced persons

At this point, it becomes imperative to shed some light on the fact that having not ratified any of the above conventions to the cause of the Chagossians is not at all accidental. Mauritius had realised that the ratification of these treaties would increase its responsibility and accountability to the UN committee, subsequently putting at stake the rule-of-law abiding image that Mauritius presents on the international stage. It is also remarkable that while UK can claim that the conventions do not apply to the BIOT using the excuse of extra territoriality, the fact Diego Garcia is included in the territories of Mauritius in the Constitution makes it problematic for the latter to evade its responsibilities towards the Chagossians.

Responsibilities of Mauritius under customary international law towards the stateless Chagossians

As shown earlier, the Universal Declaration has an incontestable 'political standing and symbolic importance' and it remains an authoritative enumeration of universally recognised human rights which constitutes an obligation for state parties to abide by their responsibilities towards all members of the human family (Hannum, I996: 287). In this respect, the responsibilities of Mauritius will be analysed through the lens of the Universal Declaration.

Article 2 of the Universal Declaration emphasizes the prohibition of discrimination. Hence, Mauritius has an obligation not to discriminate against the Chagossians or to be involved in practices such as segregation which heightens marginalisation. Besides, Mauritius has a highly educated population which is its biggest asset. Nevertheless, due to the marginalisation of the Chagossians, many of the stateless persons who came to Mauritius in their teenage years did not have access to education. Consequently, this dearth of formal training has a negative impact in many spheres of their lives, most particularly in their compromised ability to make necessary provisions for their families 
as they depend solely on the unskilled labour market. Hence pertaining to the issue of non-discrimination, Mauritius has a positive obligation to adopt a human rights based approach to confer skills based training on the Chagossians so that they can incorporate the workforce accordingly instead of relentlessly having to remain on the lowest rung of the ladder.

Mauritius is also bound under article $\mathrm{I} 3$ of the Universal Declaration. Hence, if Mauritius is claiming sovereignty over the land, it has the positive obligation to be involved in the effort to raise awareness of the Chagossian issue in the international community and fight for their right to return. It is also remarkable that the UN Commission on Prevention of Discrimination and Protection of Minorities also attached the rights of minorities under this article in the travaux preparatoires of the drafting of the Universal Declaration. Hence, in the Chagossians case, the fact that they are considered as minorities also places an obligation on Mauritius to respect their right to return.

Together with this, Mauritius also has a responsibility towards the stateless Chagossians under article I4 of the Universal Declaration which provides for that:

I. Everyone has the right to seek and to enjoy in other countries asylum from persecution.

2. This right may not be invoked in the case of prosecutions genuinely arising from non-political crimes or from acts contrary to the purposes and principles of the United Nations.

Nevertheless, the forceful expulsion of the Chagos Islanders and the role played by Mauritius therein was a political crime of sorts. The harsh reality that they were forcibly made to agree to leave through methods such as mental torture and threats does not at all imply their consent. Hence, in order to circumvent tyranny and oppression, they came to find refuge in Mauritius. In this respect, irrespective of the fact that these vulnerable people do not qualify for Mauritian citizenship under the constitutional law of Mauritius, the State still has the obligation of providing asylum status to them. It should be underlined here that by depriving them of a nationality, Mauritius is in fact acting in breach of Article I5 of the Universal Declaration which provides for that:

I. Everyone has the right to a nationality.

2. No one shall be arbitrarily deprived of his nationality nor denied the right to change his nationality.

The fact that Article I5(2) elaborates on the arbitrary non-deprivation of the right to a nationality actually reflects the significance it confers to the dignity of the individual. Indeed, an individual is recognised through a state and hence despite having given citizenship to the children born to the Stateless Chagossians (for the reason that they were born on Mauritian Territory) Mauritius' responsibility extends to a duty to provide the same to the Stateless Chagossians. Moreover, it also has the charge of furnishing any kind of help to any endeavour undertaken by the Chagossians wishing to take up refugee status or wishing to seek asylum in the UK where some members of their families are already settled. 


\section{Recent developments}

In 20I4, the Mauritian government initiated actions against the UK government for declaring the area around the Chagos as the world's largest Marine Protected Area which has resulted in restricted access to the Island by the Chagossians. In the Matter of the Chagos Marine Protected Area Arbitration (Mauritius v UK), an award was delivered on the I 8 March 2015 by the United Nations Permanent Arbitration Court, seized as a tribunal constituted under Annex VII of the UN Convention on the Law of the Sea (UNCLOS). This award finds it relevance not only by shedding light on the enormously tricky question of sovereignty over Chagos but equally in the wake of the coming to term of the 50-year-old lease of the Chagos by UK to the US for defence purposes in 20I6. The award will have an impact on the question of renewal of the lease next year.

The arguments of Mauritius before the Tribunal were four-fold. Firstly, it was illegal for UK to declare a MPA since it is not a coastal state under the UNCLOS. Secondly, unilaterally declaring the MPA has violated the rights of Mauritius as a coastal state under the UNCLOS. Thirdly, the should not be allowed to prevent the Commission on the Limits of the Continental Shelf from making recommendations to Mauritius on the issue should a full submission be made to the Commission. Finally, substantive and procedural obligations under the UNCLOS were not respected by UK.

The tribunal ruled that it only had jurisdiction on the fourth submission of Mauritius and more precisely its claims under the ambit of articles 2, 56, I94 and 300 of the UNCLOS. It is interesting to note that two of the five judges namely Judges Wolfrum and Kaketa dissented from this stand of the Tribunal to say that the first two submissions equally and directly concerned the UNCLOS and the Tribunal ought to have jurisdiction.

In essence the award of the Tribunal revolved around the unsatisfactory manner in which the UK engaged in meaningful and concrete consultation with Mauritius before declaring the MPA. It explained that in the same way thatthe US was consulted in the matter before declaring the MPA Mauritius ought also to have been consulted (Mauritius v UK, 20I5: 528). According to the Tribunal, the UK failed to balance its own rights and interested with those of Mauritius especially when it came to fishing rights in the MPA. A breach of articles 2, 56 and 194 by UK was declared by the Tribunal thus rendering the creation of the MPA by UK as illegal.

Perhaps of more interest in the award is the partial dissenting opinion of Judges Kaketa and Wolfrum. They highlighted that it was regrettable that the Tribunal failed to consider the legality of the detachment of Chagos from Mauritius under the lens of utipossidetis and the right to self-determination especially taking into account that Mauritius had no choice but to accept the detachment which amounted to duress. The blatant non-respect of the rights and interests of Mauritius was noted by the Judges in the dissenting opinion. ${ }^{2}$ 


\section{Conclusion}

It is clear that the fundamental human rights of the helpless Chagossians have been violated by depriving them of the right to return to their own country. All the states involved in forcing the Chagossians to go through such an ordeal did not even show any respect or adherence to customary international law while ejecting the Chagossians from their own homeland. At this point in time, it becomes rather obvious that the issue of the Chagossians was the blend of a very complex interplay of international human rights law and politics. However, in the wait for justice to be done, the subsequent recommendations to the UK and Mauritius may help in the mitigation of the anguish of the Chagossians. It is important for the UK to realise that compelling the Chagossians to leave their territory which by full rights belong to them resulted in massive human rights violations. In addition, carried out the evictions on the back of fabrication worsens the situation as this is both spiteful and a severe injustice in the domain of human rights.

It is argued that UK genuinely intends to repeal the BIOT (Immigration) Order Act and the BIOT (Constitution) Act. The main reason being that a law most particularly in a country that contends to sustain democratic and good governance principles should be pro-people instead of pro-establishment and also as alterations in legislations and policies are intended to improve and enhance the lives of individuals and not to degenerate them. The UK should also simplify and back the Chagossians' right to an immediate return to the islands as they acquired the sovereignty over the land. Since the UK deals with administrative matters and considering that fact who gets to stay on the land is debatably an administrative matter, it should exercise its power to voice its opinion and see justice done to the Chagossians should it renew the lease for the US.

Additionally, the UK should pay the Chagossians satisfactory compensation for the violation of their rights over the past 40 years as the one-off payment of $£ 65$,000 was not sufficient for the resettlement of the Chagossians. The UK therefore has an obligation to properly consult with and seek informed consent of the Chagossians with regard to the return and compensation process. UK should adhere to its duties, responsibilities and obligations under international human rights law and refrain from getting involved in the seemingly selective application of the diverse conventions and Charters.

As for Mauritius, it needs to reveal to the Chagossians what really happened during the independence negotiations and comprehend that giving way before compulsion or pressure was not the right course of action. Besides, it should also open its eyes to fact that trying to further political ambitions at the expense of permanent displacement of others was nothing but an abuse of the dignity of the Chagossians. Mauritius should respect its commitments under international human rights law and by virtue of being a welfare state make ample arrangements so that the socio economic and cultural rights of the Chagossians are respected. Mauritius should also implement an integrationist approach pertaining to education and employment prospects of Chagossians to fight the scourge of racial discrimination and marginalisation that further propagates the misery of the

can defence interests were put above Mauritius' rights. Fast forward to 2010 and one finds a similar disregard of Mauritius' rights, such as the total ban on fishing in the MPA. These are not accidental happenings (para. 9I). 
Chagossians. Mauritius should adopt the principle of affirmative action concerning the Chagossians bearing in mind that they have been marginalised in many dissimilar fields and denied a decent standard of living in contrast with other Mauritian counterparts.

Irrespective of the fact that Mauritius claims to be a secular state, religion often permeates the psyche and many political decisions are fuelled by the religious ideas. Subsequently, the state should make sure that religious groups and associations do not use the vulnerability of the Chagossians as a means of pushing their own agenda forward. Mauritius should make amendments in its legislation with respect to the Chagossians who are stateless. Despite the fact that the international convention on the reduction of statelessness may not apply to Mauritius, the Universal Declaration in its globality obliges Mauritius to resolve the issue of non-discrimination and equality in its national legislation.

Mauritius should continue to lobby the international community for amplified support of the Chagossians cause. Mauritius should also attempt to achieve more assistance from the AU and its member states to make its case stronger in accordance with the denuclearisation of the African continent. Mauritius should not be a deterrent to the Chagossians who wish to move to the UK to stay with the members of their families who have British citizenship. Mauritius should ratify the international conventions on refugees and statelessness so as to be able to gather more support to achieve its goals of giving the Chagossians equal opportunities.

It is highly significant that the international community makes use of platforms such as UPR where the naming and shaming approach is adopted to oblige the UK and Mauritius to allow the Chagossians the right to return. Both countries as well as the international community need to react urgently on this issue, or else the violations will continue and affect the coming generations of Chagossians. The award from the UN PCA does come with an ray of hope especially with the dissenting opinion which at least can be effective in mobilizing opinion on the detachment of Chagos and the ensuing human rights violations.

\section{References}

Abraham, Garth (20II). Paradise claimed: disputed sovereignty over the Chagos Archipelago. South African Law Journal, I3: 128 .

Boolell, Sachita (2010).Untold Stories: Diego Garcia. Mauritius, 29.

Crawford, James (1999). Reviewing the difficulties of codification. European Journal of International Law, Io: 372.

Curtis, Mark (1998). Web of deceit: Britain's real foreign policy, Britain's real role in the World. UK: Vintage, 24.

Geoffrey, Robertson (2012). Who Owns Diego Garcia? Decolonisation and Indigenous Rights in the Indian Ocean. Western Australia Law Review, I2:6.

Gifford, Richard (2004). The Chagos Islands - The land where human rights hardly ever happen. Law, Social Justice \& Global Development, 4: 2.

Hannum, Hurst (1995). The Status of the Universal Declaration of Human Rights in National and International Law. Georgia Journal of International and Comparative Law, 25: 287.

Jeffery, Laura (2006). Historical narrative and legal evidence: judging Chagossians' High Court testimonies'. Political and Legal Anthropology, 29: 230. 
Langford, Michael (2012). Global Justice, State Duties: The Extraterritorial Scope of Economic, Social, and Cultural Rights in International Law. UK: Cambrigde, 33.

L'Estrac, Jean (20II). Next year in Diego Garcia. Mauritius: Edition Le Printemps, 35.

Sookhoo, Nairanduth (2013). Mauritius Independence: Myths and Realities. Le Mauricien, Mauritius.

Snoxell, David (2009). Debate: Anglo/American Complicity in the Removal of the Inhabitants of the Chagos Islands. The Journal of Imperial and Commonwealth History, 37: 130.

Tong, Michael (2009). The right to self-determination and restitution: the matter of the people of the Chagos Archipelago (British Indian Ocean Territory). Unpublished PhD Thesis, Universite de Strasbourg, Io.

Vine, David (2005). Dérasiné: the Expulsion and Impoverishment of the Chagossian People. Washington: American University Law School, 5 .

Vine, David (2006). The Impoverishment of Displacement: Models for Documenting Human Rights Abuses and the People of Diego Garcia. Human Rights Brief, 2I.

\section{Websites}

J. Pilger "Stealing a nation" (22 September 2015) johnpilger.com, available at: <http://johnpilger.com/ videos/stealing-a-nation > (last accessed 22 September 2015).

N. Ando "General comments and recommendation" Max Plank Encyclopedia for Public law, available at < http://ilmc.univie.ac.at/uploads/media/general_comments_recommendations_empil.pdf> (last accessed I October 2014). 